\title{
ANALYZING MOBILE PHONE USAGE IN AGRICULTURAL MODERNIZATION AND RURAL DEVELOPMENT
}

\author{
aNawab Khan* bBadar N. Siddiqui, cNanak Khan, dFarhatullah Khan, eNaqeeb Ullah, fMuhammad Ihtisham, \\ gRahmat Ullah, hSohaib Ismail, iSyed Muhammad \\ ${ }^{a}$ College of Management, Sichuan Agricultural University Chengdu Campus, Wenjiang 611100, Sichuan China. \\ ${ }^{b}$ Department of Agricultural Extension, PMAS-Arid Agriculture University Rawalpindi, Pakistan. \\ ${ }^{c}$ Department of Agronomy, Baluchistan Agriculture College, Quetta, Pakistan. \\ ${ }^{d}$ Department of Agricultural Extension, Allama Iqbal Open University, Islamabad, Pakistan. \\ ${ }^{e}$ Directorate of Post-Harvest and Food Technology Agriculture Research Institute ARI Sariab Quetta, Pakistan. \\ ${ }^{f}$ College of Landscape Architecture, Sichuan Agricultural University Chengdu Campus, Wenjiang 611100, Sichuan China. \\ $g$ Department of Agriculture Extension, Baluchistan Agriculture College, Quetta, Pakistan. \\ ${ }^{h}$ Department of Plant Pathology, Sichuan Agricultural University, Chengdu 611130, China. \\ I Shaheed Benazir Bhutto University, Sheringal, Upper Dir, Khyber Pakhtunkhwa, Pakistan.
}

\section{ART ICLE IN F O}

\section{Article history}

Received: April 21, 2020

Revised: June 19, 2020

Accepted: August 18, 2020

\section{Keywords}

Analyzing

Mobile phone usage

Agricultural and rural

development
A B S T R A C T

The agricultural sector worldwide is facing many issues relating to crop productivity due to the lack of communication between extension workers and farmers. To reduce this gap, information technology like mobile phones are one of the essential communication devices in numerous fields as well as agriculture. This review aims to analyze mobile phone usage in agricultural modernization and rural development. The advancement of the agricultural sector in rural areas is essential for reducing poverty among growers. As we all know, agricultural activities provide employment opportunities and generate income in rural areas. Poverty can be decreased by advancement in the agriculture sector for better production. Agriculture production, socioeconomic conditions, and food security can be improved by increasing the usage of mobile phones for easy and accurate agricultural knowledge sharing to the farming community.

Corresponding Author: Nawab Khan

Email: nawabk5554@gmail.com

(C) The Author(s) 2020.

\section{INTRODUCTION}

Sustainable agricultural systems require research-based agricultural practices that rely on advanced mobile phone technology to share and transfer agricultural knowledge. Using suitable tools to disseminate information is vital to sustainable agricultural development in the 21st century (Ashraf et al., 2018; Kumar and Karthikeyan, 2019). The agriculture and food sectors confront numerous challenges. As the worldwide population is expected to grow up from 7.6 billion in
2018 (Department of Economic and Social Affairs 2019), to more than 9.7 billion in 2050, the requirement for food will rise significantly (Department of Economic and Social Affairs, 2017). Simultaneously, the accessibility of natural sources such as clean water and productive land is increasingly restricted.

Although current agricultural production is insufficient to feed the globe, eight hundred forty-one million people even now endure hunger (FAO, 2018). Procedures such as fast growth also have crucial consequences for food 
production and consumption patterns. The agri-food segment remains vital for employment and livelihoods. There are more than $\mathbf{5 7 0}$ million farms globally, most of which are small, and family operated. (Lowder et al., 2016; ILOSTAT, 2019).

Digital development and equipment/skills might be part of the resolution. The so-called "Fourth Industrial Revolution" (Industry 4.0) is rapidly changing several industries through "disruptive" digital technologies (for example, immersive reality, blockchain, and artificial intelligence). In agri-food, the popularity of mobile phone technology, services of remote sensing, and disseminated computing have been improving small farmers' access to knowledge, markets, inputs, training, and finance. Digital skills are producing different opportunities to include smallholder growers in digitally motivated systems of agri-food (USAID 2018; Kumar and Karthikeyan, 2019).

There are not many review articles allied to this title, so it can be an opportunity to other investigators whose studies are like this review article and title used as a reference that can benefit as an instruction or guideline in the future. Moreover, it can suggest direction and provide better knowledge for further study, extension, and advancement for non- government organizations whose key concern with farming information by mobile phone or ICT in general. It is very much essential to examine mobile phone usage in agricultural modernization and rural development. This information will support to reshape the existing transfer of skill or new technology programs in such a way through using the mobile phone technology so that information or knowledge will be dispersed in an efficient and better way.

This article covers five main sections. The first part is the agriculture and food sectors. The second part includes agriculture information distribution through mobile phones. The third section role of research and extension in agricultural modernization. The fourth part is the future role of mobile technology in agricultural development. The final section is a conclusion.

\section{Agriculture Information Distribution Through Mobile Phones. Mobile Phone}

A mobile phone (as well-known as a handphone, cell phone) is a type of phone that can create and have calls over a radio link whereas moving through a broad geographical area. This is done by linking to a cellular network offered by the handphone worker, accepting access to the public cellular phone network. In contrast, cordless phones are only used within a short range of a single dedicated base station. In addition to phones, new mobile also helps a variety of other essential services, for example, text messaging, multimedia messaging, Internet access, email, short-range wireless telecommunications (Bluetooth, infrared), applications of business photography and gaming. Cell phones that provide these and more conventional computing functions are called smartphones (Kumar and Karthikeyan, 2019).

\section{Role of mobile phones in agriculture development} Information and communications technology (ICT), especially mobile phone technology, has penetrated every area of life, such as commerce, education, business, and agriculture (Sharma 2016; Sharma 2019). Mobile technology-based communication has recently developed rapidly and has become the most frequently used communication device among all other ICTs today (Bhatnagar 2008; Mittal 2010; Manimekalai 2013; Khan et al., 2019). The latest statistics reveal that 62.9 percent of the world's population now has a cell phone, and there are 4.68 billion operators/customers and users on the globe (Statista 2019). This fast development of mobile phones has become a useful communication tool, which has not only changed the way many departments work but has also produced new skilled fields for different industries as well as agriculture (Jansen et al., 2006; Sullivan and Omwansa 2013; Asongu and Asongu 2018; Khan et al., 2019). In the farming sector, the smooth conversation of information is important for the effective adoption of farm innovations required for the advancement in farming. Due to the deficiency of resources and deprived infrastructure in various developing nations, there is a massive communication irregularity between modern farming information and growers. (Baloch and Thapa, 2014; Khan et al., 2019). In this context, ICTs (especially cell phones) reveal the huge potential to help exchanges by smooth knowledge exchange among various sponsors in agriculture (Aker, 2011). In agriculture, cellular phones enable growers to communicate at the local as well as at the organizational level in agricultural trade, knowledge exchange, and agricultural products (Fafchamps and Hill 2005; Rathore and Sharm, 2012; Ogutu et al., 2014 and Khan et al., 
2019). This reduces travel costs and increases the productivity of agricultural communities living in remote areas. Compared to other ICT tools, mobile phones have been widely spread to marginalized and underdeveloped agricultural communities due to their affordability and user-friendliness (Rashid et al., 2009; Brugger, 2011; Payne et al., 2011; Osabutey and Jin, 2016). Another aspect of the application of mobile phones in farming is "electronic extension," which simplifies the model of extension and consulting services by playing a useful role in communication between agricultural communities and research corporations (Aker and Ksoll, 2016). Usually, farm consulting services in several countries are provided through extension techniques: for example, growers' meetings, mass discussions, personal visits, etc. (Faostat and Production, 2016). Unfortunately, the present percentage of extension workers to growers cannot meet the knowledge needs of agricultural communities (Baloch and Thapa, 2014). For example, in various developing nations, due to limited resources, current agricultural extension systems cannot meet growers' information needs (Aker 2011). In this concern, rising trends in the use of ICT for extension and consulting services are widespread in many advanced and developing nations (Aker and Ksoll 2016). The claim that communication technology is the future of agricultural extension and that the country can no longer pay for the cost of the face-to-face method is widely praised because cell phones may replace face-to-face extension systems (Aldosari et al., 2017).

The mobile phones play a beneficial role in agricultural development in various developing nations, but in some cases, the growers faced more agricultural knowledge challenges, thereby lack of access to the latest agricultural technologies (Chambers, 1985; Ratnam et al., 2006, Cantor, 2009; Goyal, 2010; Rehman et al., 2015; Muddassir et al., 2016; Noor et al., 2016 and Ahmad et al., 2016). Information is essential for improving farming production and enhancing marketing. (Oladele, 2006; Donner, 2008; Kalba, 2008 and McNamara, 2009). Ultimately, increasing the importance of agricultural production depends on the country's ability to distribute central information to the agricultural communities to promote new production technologies, soil and water conservation technologies, and agricultural information resources (Kiplagat 1998; Kumar and Karthikeyan, 2019).
There are various mobile phone companies around the world, such as I-phone, Galaxy, Q mobile, and HTC. Most companies recommend $3 \mathrm{G}$ and $4 \mathrm{G}$ tools to their clients, enabling them to access the Internet through their cell phones. Access to agricultural knowledge, affordability, and efficiency are the main constraints to improving small-scale growers' agricultural productivity (Murithii 2009; Vodafone 2010; Islam and Gronlund, 2011). Mobile phones provide growers with a convenient and economical way to obtain information. According to (Chisita, 2010), the use of ICT to distribute farming knowledge has great potential, enabling small-scale growers to communicate information and knowledge by leveraging telecentres, social media, and other ICTdriven transmission tools. It needs to be further stressed that in this era of the knowledge, no one disregards the advantages of information equipment because they are hardly accessing the areas where digital, information, and communication technologies can be involved. According to Tantisantisom (2011), using ICT to learn new skills and useful agricultural production techniques in their personal language may help growers to adopt improved systems and enhance their farming production (Leye, 2009; Ballantane et al., 2010; Armstrong et al., 2011 and Kirk et al., 2011; Kumar and Karthikeyan, 2019).

In addition, cell phones can deliver information via calls, WhatsApp, text messages, and search appliances. From the previous study, growers have sought nine significant types of agricultural information: insect pest control information, farm safety information, variety information, pesticide/weed information, farming practice knowledge, loan/subsidy information, information of crop production, marketing information, and Climate information (Munyua 2000; Mittal and Tripathi 2008 and World Bank 2011). the most standard communication function/toll is WhatsApp followed by Facebook, Messenger, WeChat, and Telegram (98.1\%), (55.6\%), (36.8\%) and (25.0\%) respectively. The findings indicate that the WhatsApp app can support our society to broadly distribute and share information regarding agriculture and rural development (MCMC 2018 and Ramli et al., 2019).

\section{Constraints in farm-related use of mobile phone}

The results of the present review also report several restrictions on growers' use of mobile technology. Based on the survey results, growers recognized two major 
constraints: "the difficulty of understanding knowledge via robocalls " and "constrained ability to use mobile phones (call only) (averages 4.02 and 4.12). The limited use of mobile phones shows that grower's basic information about mobile phone use is inadequate for making and receiving calls that are explained in the earlier portion. The results are consistent with other surveys that also show that digital illiteracy is the main constrain of mobile phone use by farmers (Mittal and Tripathi, 2010; Osabutey and Jin, 2016; Surabhi and Mamta, 2016 and Saroj et al., 2017). Presently, most agricultural information comes from resources such as websites, internet portals, mobile android applications, and e-magazines (Manjuprakash et al., 2016). Correspondingly, in Pakistan, different ICT-based farming information resources have been launched, such as network extension, ICT-facilitated community centers, Bakhabar Kissan (well-known growers), and UAF clinics to provide agriculture information for Pakistani growers (Jallo, 2016 and Jazz, 2018). These various resources of knowledge require Internet access and improved operational skills, and unfortunately, growers lack this information in the research area. Similarly, growers pointed out the problem of knowing through mobile phone automatic calls, because in certain cases, these pre-recorded information services based on voice calls could not meet the growers' information needs, and sometimes could not clarify thereby unclear information. There are similar reports in India (Shankaraiah and Swamy 2012; Baloch and Thapa 2014).

\section{Advantages of mobile applications}

The inevitability and growing significance of agricultural offers provide many benefits. Growers have access to any type of information regarding crops, seeds, soil, rainfall, climate, and machinery anytime, anywhere (World Bank, 2011). The knowledge accessible is localized for added comfort and precision as needed. This material is regularly updated and delivered through various methods and application modules, and growers should not worry regarding obtaining information from other resources. The existing information is organized and well-organized, and cultivators do not need to waste time on retrieval and recommendation (Kirk et al., 2011). Market connectivity has also been enhanced through the local presence and information of prospective buyers and sellers, as well as the opportunity to establish direct contacts. Product costs can be provided in actual time. Mobility can support growers build better storage facilities by modernizing inventory, tracking inventory, recording purchase needs, and fulfilling delivery commitments in an appropriate manner so that inventory makes the final customer while ensuring superiority (Kuek et al., 2011; Muto and Yamano, 2011; Lee and Bellemare, 2013). Besides, this facilitates purchasing and selling commodities locally and supports them in tracking their buying and selling needs. Growers can better understand their assets, track purchase orders, viewpoint bank statements, fully understand insurance details and targets, and effectively plan production (Baumuller, 2012).

\section{Disadvantages of mobile applications}

Although mobility has its advantages, it also has some disadvantages. Due to the diversity of languages, even the most excellent applications that do not help local languages require translation at all phases, which will boost dependencies and reduce suitability and popularity (Cantor, 2009; Aguero, 2009; Rashid et al., 2009; Kuek et al., 2011 and Manimekalai 2013). Sometimes, due to network issues, data transfer speeds, legal restrictions, it may not be possible to obtain updates and complete information (Kirk 2011). Specialists may be needed to understand and translate the various complex functions to be performed on the farm, info, and videos in other languages (Baumuller 2012). Growers in developing countries may not have enough capacity to provide and use applications that may be accused, and a large amount of the use of data has increased the burden of growers on the Internet (World Bank, 2011).

\section{Role of Research and Extension in Agricultural Modernization}

The research and extension department is an important source for the adoption and dissemination of any agricultural equipment among farmers. The requirement is extension employees ought to frequently intervene in growers' activities and play a key role in educating and distributing any type of knowledge and new technology. With fair use of cell phone, farmers have easy access to information about markets, weather, and other consulting services (World Bank 2003; Anderson and Feder, 2003; Acacia 2006; Ilahion, 2007; McNamara, 2009; FAO, 2010; Aker, 2011; Qiang, 2011; FAOSTAT, 
2016; Aker and Ksoll, 2016). According to mobile phones, cellular technology has totally changed the way growers exchange knowledge with each other and cooperate with cities, markets, and enables growers to extract important data for decision-making.

\section{The future role of mobile technology in agricultural development}

Currently, 95 percent of people globally live in areas covered by mobile networks, and by 2021, more than 90 percent of modern phone subscribers are expected to be in developing countries. Preceding research on mobile phone development has often led to arguments that ICTs can promote rural development and poverty decline (Donner, 2008; Awuor et al., 2013; Duncombe and Heeks, 2002 and Richardson et al., 1998). It is pointed out that due to changes in agricultural technology, agricultural policies, environmental changes, and the advent of farming modernization, growers' information needs will change from time to time. Similarly, the surveyed literature highlights the rapid growth of mobile phones in emerging Asian developing nations and their crucial role in decreasing the price of knowledge search and boosting market productivity.

In addition, the capabilities of mobile technology can bring new impetus to the agricultural sector. According to the fastest way out of poverty, at present is to own a cell phone. (Baye et al., 1999; Aker, 2008; Aker, 2011; Yunus, 2011; Chhachhar and Hassan, 2014), An example showing the widespread use of mobile communication technology in agriculture is "cell phones." It has been used to obtain knowledge on market rates, weather conditions, and several other phases (Pickernell et al., 2004; Abraham, 2007; Silarszky, 2008 and Muto, 2009; Kumar and Karthikeyan, 2019). Though, relevant agencies should address issues such as lack of connectivity and poor service quality, particularly in rural parts, so that growers can appreciate the advantages of cell phones. Rural growers often confront information gaps in agricultural best methods. Cell phone services can help bridge the knowledge gap, thereby enhancing farming production.

\section{CONCLUSIONS AND RECOMMENDATIONS}

Faced with extreme challenges in the process of transferring information to growers around the world. Cell phone-based consulting services have become an efficient alternative that changes the traditional method of extension knowledge exchange. Present research in this area focuses on analyzing mobile phone usage in agricultural modernization and rural development. The results report that most growers own a mobile phone, but they only use basic operating proficiencies for calls. Due to this inadequate ability of cell phones, growers cannot access knowledge from different Internet-based information suppliers such as android applications and Web portals. There is an urgent requirement to educate and train growers to understand how to use these accessible sources of knowledge to take advantage of the true capacity of cell phones. The present research also suggests that specialists in the field of electronic extension consider growers' digital literacy before starting ICT-based programs in such rural areas.

In addition, a capacity-building plan is needed, which will result in acquiring the necessary skills to enhance the use of provided content. This shows a lack of awareness among growers of the sources of knowledge available and the attention of decision-makers to mainstream these programs. This can be achieved through advertising campaigns organized by relevant growers' departments, which is the main goal of these projects. On the contrary, it also shows the great capability of the private sector in providing services, and public sector organizations can learn from it. In this regard, public sector agencies and policymakers need to work hard to focus on these ICT-based initiatives, as this is a contemporary model of extension, and states cannot pay for the number of face-to-face methods of extension. In summary, it can be assumed that mobile applications play a vital role in the advancement of the rural population. Growers can obtain knowledge about agriculture through various apps. There are various applications, such as soil health card application, marketing application, m-Kishan, etc., which deliver the best material at the appropriate time to the farmers and other stakeholders. ICTs in developing nations are continually evolving in order to accommodate the diverse populations of doctors, educators, and agricultural scientists. Growers are one of the large communities worldwide, where their areas do not have facilities to improve products and income. Cell phones among growers are increasing, but there are still gaps among customers, growers, and businesses. Various projects on cell phone technology are necessary to be improved so that growers can easily connect with citizens to sell their commodities on the market. The 
government and other relevant departments must also plan to link these growers and provide timely updates on seeds, markets, and weather, and deliver reasonable product prices.

\section{REFERENCES}

Abraham, R. 2007. Mobile Phones and Economic Development: Evidence from the Fishing Industry in India, Information Technologies and International Development, 4 (1): 5-17.

ACACIA, 2006. ACACIA Prospectus 2006-2011. http://www.idrc.ca/acacia/ev-113431-201-1DO_TOPIC.htlm.

Agüero, A. 2009. Education, mobile phone use and production decisions: a rural case study in Peru. In Mobile 2.0: Beyond Voice?" Pre-conference workshop at the International Communication Association, Pp, 1-21.

Ahmad, W., Noor, M., Afzal, I., Bakhtavar, M., Nawaz, M., Sun, $\mathrm{X}$ and M. Zhao. 2016. Improvement of sorghum crop through exogenous application of natural growth-promoting substances under a changing climate. Sustainability, 8(12):13-30.

Aker, J. C and C. Ksoll. 2016. Can mobile phones improve agricultural outcomes? Evidence from a randomized experiment in Niger. Food Policy, 12(60):44-51.

Aker, J. C. 2008. Does Digital Divide or Provide? The Impact of Cell Phones on Grain Markets in Niger, Job Market Paper. Pp, 64.

Aker, J. C. 2011. Dial "A" for agriculture: a review of information and communication technologies for agricultural extension in developing countries. Agricultural Economics, 42(6):631-647.

Aldosari, F. O., Al-Sakran, M. S., Alkhubizi, F. N., Al-Zaidi, A. A., Baig, M. B., Muddassir, M and M. Mubushar. 2017. Use of cell phones by the farmers as an extension tool to practice sustainable agriculture and achieve food security in the Kingdom of Saudi Arabia. Journal of Experimental Biology and Agricultural Sciences, 5(1):1-8.

Anderson, J. R and G. Feder. 2003. Rural Extension Services. The World Bank, Policy Research Working Paper 2976.Washington, DC.

Armstrong, L. J. and N. Gandhi. 2012. Factors influencing the use of Information and Communication Technology (ICT) tools by the rural farmers in Ratnagiri district of Maharashtra, India,
Proceeding of the AIPA 2012, IIIT, Hyderabad, 1st to 3rd August 2012, Hyderabad, India.

Ashraf., E, Hafiz K, S and I. Mujahid. 2018. Creating Awareness Among Farmers for the Use of Mobile Phone Cellular Technology for Dissemination of Information Regarding Aphid (Macrosiphum Miscanthi, Hemiptera, Aphididae) Attack on Wheat Crop, Sarhad Journal of Agriculture, 34(4):724.

Asongu, S and N. Asongu. 2018. The comparative exploration of mobile money services in inclusive development. International Journal of Social Economics, 45(1):124-139.

Awuor, F, Kimeli, K, Rabah, K and D. Rambim. 2013. 'ICT solution architecture for agriculture'. In IST-Africa Conference and Exhibition (IST-Africa), Pp17.

Ratnam, B.V., P. K. Reddy, and G. S. Reddy. 2006. e-sagu: An IT-based personalized agricultural extension system prototype - analysis of 51 Farmers' case studies, International Journal of Education and Development using ICT, 2(1): 79-94.

Ballantyne, P., Maru, A and E. M. Porcari 2010. Information and communication technologiesopportunities to mobilize agricultural science for development. Crop Science, 50(1):1-63.

Baloch, A. M and B. G. Thapa. 2014. Agricultural extension in Balochistan, Pakistan: Date palm farmers' access and satisfaction. Journal of Mountain Science, 11(4):1035-1048.

Baumüller, H. 2012. Facilitating agricultural technology adoption among the poor: The role of service delivery through mobile phones. Pp,35.

Bayes, A., von Braun, J and R. Akhter. 1999. Village Pay Phones and Poverty Reduction: Insights from a Grameen Bank Initiative in Bangladesh, Center for Development Research (AEF), University at Bonn, Discussion papers on development policy No, 8. $\mathrm{Pp}, 54$.

Bhatnagar, S. 2008. Benefits from Rural ICT Applications in India: Reducing Transaction Costs and Enhancing Transparency, LIRNE Asia presentation at public lecture on ICT in Agriculture, Colombo, Sri Lanka,25 February 2008.

Brugger, F. 2011. Mobile Applications in Agriculture, Syngenta Foundation, mAgriculture. Pp 1-38.

Cantor, E. 2009. Reaching the Hardest to Reach: Mobile apps for low-income communities. In Mobile Web Africa Conference. 
Chhachhar, A. R. and M. S. Hassan. 2014. The Use of Mobile Phone Among Farmers for Agriculture Development. European Journal of Scientific Research, 119(2): 265-271.

Chisita, C. T. 2010. An investigation into the use of ICT in the provision of agricultural information to small scale farmers in Harare. In World Library and Information congress: 76th IFLA General Conference and Assembly (pp. 10-15).

Donner, J. 2008. Research approaches mobile use in the developing world: A review of the literature. The Information Society, 24(3):140-159.

Donner, J. 2008. Research approaches to mobile use in the developing world: A review of the literature, The Information Society, 24(3): 140-159.

Duncombe, R and R. Heeks. 2002. Enterprise across the digital divide: information systems and rural microenterprise in Botswana. Journal of International Development: The Journal of the Development Studies Association, 14(1):61-74.

Fafchamps, M, and R. V. Hill. 2005. 'Selling at Farmgate or Traveling to Market." American journal of Agricultural Economics, 87(3):717-734.

FAO, 2010. Mobilizing the potential of rural and agricultural extension. Ian Christoplos, Danish Institute for International Studies, Rome, pp,64.

FAO, 2018. The State of Food Security and Nutrition in the World: Building Resilience for Peace and Food Security. Rome: FAO (available at: http://www.fao.org/news/story/ en/item/1152031/icode/)

FAO. 2017. Information and Communication Technology (ICT) in Agriculture: A Report to the G20 Agricultural Deputies. Rome: FAO.

Faostat, F. A. 0 and A. C. Production. 2016. Food and agriculture organization of the united nations, 2010. Roma, Italy.

Gayatri, C. B and R. Arunachalam. 2016. Use of Modern Electronic Gadgets in Effective Transfer of Agricultural Technologies. Journal of Global Communication 9 (conf): 188-195.

Goyal, A. 2010. Information, Direct Access to Farmers, and Rural Market Performance in Central India, American Economic Journal: Applied Economics. 2 (3): 22-45.

Ilahiane, H. 2007. Impacts of ICTs in agriculture: Farmers and mobile phones in Morocco. In American Anthropological Association
Conference, Washington, DC United States of America. 1(3): 24-40.

ILOSTAT, 2019. Employment database. Geneva: International Labour Organization. [Data retrieved May 2019].

Islam, S. M, and A. G. Gronlund. 2011. 'Factors influencing the adoption of mobile phones among the farmers in Bangladesh: Theories and practices. International Journal. on Advanced in ICT for Emerging Regions, 4(1):4-14.

Jallo, C. 2016. Assessment of Information and Communication Technologies in Pakistan Agricultural Extension. Pp 1-36.

Jansen, H. G. P, Pender, J., Damon, A, and R. Schipper. 2006. Rural development policies and sustainable land use in the hillside areas of Honduras. A quantitative livelihood approach. Research Report 147. International Food Policy Research Institute. Washington. D C.

JAZZ. Bakhabar Kissan. Agriculture Value Added Services. 2018. Available from: <https://www.jazz.com.pk/prepaid/ bakhabarkissan/>. Accessed: Apr. 29, 2019.

Kalba, K. 2008. The Global Adoption and Diffusion of Mobile Phone, Program on Information Resources Policy, Center for Information Policy Research, Harvard University, pp2-31.

Khan, N., A, Gao. Q, Shoukat. A, Babar. S and A. S. Ashfaq. 2019. Farmers' use of mobile phone for accessing agricultural information in Pakistan: a case of Punjab province, Ciência Rural, Santa Maria, 49(10):1-12.

Kiplagat, B. 1998. Is mediation alien to Africa? perhaps in letter, but not in spirit. Track Two: Constructive Approaches to Community and Political Conflict, 7(1):1-5.

Kirk, M., Steele, J., Delbé, C., Crow, L., Keeble, J., Fricke, C and G. Bulloch. 2011. Connected Agriculture: The role of mobile in driving efficiency and sustainability in the food and agriculture value chain. Oxfam Policy and Practice: Agriculture, Food and Land, 11(6):85-106.

Kuek, C. Dymond, A. and S. Esselaar. 2011. Mobile Applications for Agriculture and Rural Development, ICT Sector Unit, World Bank, December.

Kumar, S. A., \& Karthikeyan, C. (2019). Status of Mobile Agricultural Apps in the Global Mobile Ecosystem. 
International Journal of Education \& Development using Information \& Communication Technology, 15(3):1-12.

Leye, V. 2009. Information and Communication Technologies for Development: A Critical Perspective, Global Governance, 15, pp. 29-35.

Lowder, S.K., Skoet, J and T. Raney. 2016. The number, size and distribution of farms, smallholder farms, and family farms worldwide. World Development, 8(6):16-29.

Manimekalai, S. 2013. A cognitive approach to Mobile Application in Green Commerce, International Journal of Emerging Trends and Technology in Computer Science. 2 (6): 302-304.

McNamara, K. and S. Kerry. 2009. Mobile Applications in Agriculture and Rural Development Framing the Topic and Learning from Experience, World Bank Workshop on Mobile Innovations for Social and Economic Transformation.

McNamara, K. S. 2009. 'Mobile Applications in Agriculture and Rural Development, Framing the Topic, and Learning from Experience', World Bank Workshop on Mobile Innovations for Social and Economic Transformation.

Mittal, S and G. Tripathi. 2008. Role of mobile phone technology in improving small farm productivity. Agricultural Economics Research Review, 22(347): 451-460.

Mittal, S., Gandhi, S and G. Tripathi. 2010. Socioeconomic impact of mobile phones on Indian agriculture, Working Paper No. 246. Indian Council for Research on International Economic Relations.

Mittal, S., Gandhi, S and G. Tripathi. 2010. Socioeconomic Impact of Mobile Phones on Indian Agriculture, Working Paper No. 246, 53, 24 February 2010.

Muddassir, M., Jalip, M. W., Noor, M. A., Zia, M. A., Aldosri, F. O., Fiaz, S and M. M. Zafar. 2016. Farmers' perception of factors hampering maize yield in rain-fed region of Pind Dadan Khan, Pakistan. Journal of Agricultural Extension, 20(2):1-15.

Munyua, 2000. Information Communication Technologies. International conference on Human factors in computing systems. Information Technologies and International Development, 5(1):1-15.

Murithii, 2009. Information technology for agriculture and rural development in S.Africa: Ex periences from Kenya. A Paper presented at the
International research on Food Security, Natural Resources Management and Rural development, Tropetag, Univ. Hamburg.

Muto, M and T. Yamano. 2009. The impact of mobile phone coverage expansion on market participation: Panel data evidence from Uganda. World development, 37(12): 1887-1896.

Noor, M. A., Fiaz, S., Nawaz, A and M. M. Nawaz. 2018. The effects of cutting interval on agro-qualitative traits of different millet (Pennisetum americanum L.) cultivars. Journal of the Saudi Society of Agricultural Sciences, 17 (3): 317-322.

Ogutu, S. O., Okello, J. J and D. J. Otieno 2014. Impact of information and communication technology-based market information services on smallholder farm input use and productivity: The case of Kenya. World Development, 64: 311-321.

Oladele, O. I. 2006. Multilinguality of farm broadcast and agricultural information access in Nigeria. Nordic Journal of African Studies, 15(2):34-45.

Osabutey, E. L and Z. Jin. 2016. Factors influencing technology and knowledge transfer: Configurational recipes for Sub-Saharan Africa. Journal of Business Research, 69(11):5390-5395.

Payne, J. and T. Liu. 2011. Software Platforms for Mobile Applications for Agriculture Development, International Journal of Education \& Development using Information \& Communication Technology, 15(3):55-45.

Pickernell, D. G., Christie, M. J., Rowe, P. A., Thomas, B. C., Putterill, L. G and G. J. Lynn. 2004. Farmers' markets in Wales: making the'Net work? British Food Journal, 106(3):194-210.

Qiang, C. Z. W. 2011. Mobile Applications for Agriculture and Rural Development. Washington D.C.: World Bank.

Qiang, C. Z., Kuek, S. C., Dymond, A and S. Esselaar. 2012. Mobile applications for agriculture and rural development. Pp, 414.

R. Chambers, B. P. Ghildyal. 1985. Agricultural Research for Resource-poor Farmers: The Farmer-first-andlast Model, Agricultural Administration, 20(1):130.

Ramli, N. S., Hassan, M. S., Man, N., Samah, B. A., Omar, S. Z., Rahman, N. A. and M. S. Ibrahim. 2019. Seeking of Agriculture Information through Mobile Phone among Paddy Farmers in Selangor. International Journal of Academic Research in Business and 
Social Sciences, 9(6):527-538.

Rashid, A. T. and L. Elder. 2009. Mobile phones and development: an analysis of IDRC supported projects, The Electronic Journal on Information Systems in Developing Countries, 36(2):1-16.

Rathore, S and A. Sharma. 2012. Impact of mobile phones on the lifestyle of management students of Pantnagar University. Interaction, 30(2):61-68.

Rehman, A., Jingdong, L., Shahzad, B., Chandio, A. A., Hussain, I., Nabi, G and M. S. Iqbal. 2015. Economic perspectives of major field crops of Pakistan: An empirical study. Pacific Science Review B: Humanities and Social Sciences, 1(3):145-158.

Richardson, K and F. B. Pedersen. 1998. Estimation of new production in the North Sea: consequences for temporal and spatial variability of phytoplankton. ICES Journal of Marine Science, 55(4):574-580.

Saroj, K., Nishi, S and J. Raman. 2017. Socio-personal factors with impact assessment of mobile based advisory services in Haryana. Annals of Agri Bio Research, 22(2):299-302.

Shankaraiah, N. B and K. N. Swamy. 2012. Attitude of farmers and scientists towards dissemination of technologies through mobile message service (MMS). Tropical Agricultural Research, 24(1):3141.

Sharma, A. 2016. Impact of Mobile Phone: A study in Tarai region of Uttarakhand. Journal of Computer Networking, Wireless and Mobile Communications, 6(2):11-16.

Sharma, A. 2019. Ikhedut: Successful Case Study of Mobile app for Development of Farmers, Research Explorer - A Blind Review \& Refereed Quarterly International Journal, 2(24):10-15.

Silarszky, P. Bhavnani, A. R. Chiu, W and S. Janakiram. 2008. The Role of Mobile Phones in Sustainable Rural Poverty Reduction, ICT Policy Division, Global Information and Communications Department, The World Bank, 15 June 2008.
Statista. 2019. Mobile phone users worldwide. Technology and telecommunication statistics. Available from: <https:// www.statista.com/statistics/274774/forecast-ofmobile-phoneusers-worldwide/>. Accessed: Apr. 24,2019.

Sullivan, N. P and T. K. Omwansa. 2013. Prepaid \& Payas-you-go Models for Asset Financing. Extreme Inclusion. Available from: $<$ http://www.uonbi.ac.ke/openscholar/tomwans a/files/prepaid_nicholas_

sullivan_and_tonny_omwansa.pdf $>$. Accessed: Dec. 12, 2018.

Surabhi, M and M. Mamta. 2016. Socioeconomic factors affecting adoption of modern information and communication technology by farmers in India: analysis using multivariate probit model. Journal of Agricultural Education and Extension, 22(2):199-212.

Tantisantisom, K. 2011. Information Dissemination for Farming Communities in Thailand. Ph.D. diss. Faculty of Computing, Health Sci. Edith Cowan University, Thiland.

UN DESA, 2019. Population, surface area and density. New York: UN DESA.

UN DESA. 2017. World Population Prospects: Key findings and advance tables. New York: UN DESA.

USAID, 2018. Digital farmer profile: Reimagining Smallholder Agriculture. Washington D.C.: USAID.

Vodafone, UN. (2010). Wireless Technology for Social Change: Trends in Mobile Use by NGOs, 2010.

World Bank, 2003. A Multi-Country Agricultural Productivity Programme (MAPP) for Africa. (Draft). Washington, DC.

World Bank, Information Development, 2011. ICT in Agriculture Sourcebook, Agriculture and Rural Development.

Yunus, M. 2009. Mobile telephony in rural areas. EAgriculture, Policy Brief - March 2009. Pp,1-4.

Publisher's note: EScience Press remains neutral with regard to jurisdictional claims in published maps and institutional affiliations.

Open Access This article is licensed under a Creative Commons Attribution 4.0 International License. To view a copy of this license, visit http://creativecommons.org/licenses/by/4.0/.

(C) The Author(s) 2020. 